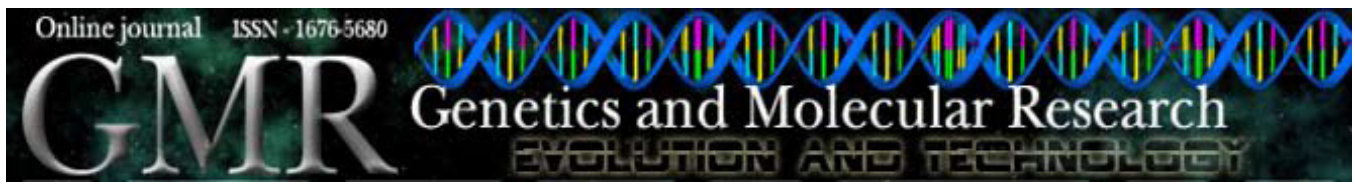

\title{
Genetic diversity studies of Brazilian garlic cultivars and quality control of garlic-clover production
}

\author{
G.S.C. Buso ${ }^{1}$, M.R. Paiva ${ }^{2}$, A.C. Torres ${ }^{3}$, F.V. Resende ${ }^{3}$, M.A. \\ Ferreira $^{1}$, J.A. Buso ${ }^{3}$ and A.N. Dusi ${ }^{3}$ \\ ${ }^{1}$ Embrapa Recursos Genéticos e Biotecnologia, Brasília, DF, Brasil \\ ${ }^{2}$ Centro Universitário de Brasília, Brasília, DF, Brasil \\ ${ }^{3}$ Embrapa Hortaliças, Brasília, DF, Brasil \\ Corresponding author: G.S.C. Buso \\ E-mail: buso@cenargen.embrapa.br
}

Genet. Mol. Res. 7 (2): 534-541 (2008)

Received April 28, 2008

Accepted May 26, 2008

Published June 17, 2008

\begin{abstract}
The garlic cultivars grown in Brazil evolved from somatic mutations and clone selection by breeding programs and by the introduction of germplasm from other countries. Morphological characters have been used to differentiate these cultivars. Two hundred and six random amplified polymorphic DNA markers were utilized for a diversity analysis of the 17 most planted garlic cultivars in Brazil. Bootstrap analysis showed that the number of markers was efficient and sufficient to obtain a coefficient of variation of $10 \%$. Similarity varied between 16 and $98 \%$ and cluster analysis showed that, in general, genetic similarities correlate with morphological characters of the cultivars and production cycle variation. High bootstrap values at most of the nodes supported the dendrogram stability. The grouping of most varieties agreed well with previous reports
\end{abstract}


based on morphological characters. As a vegetative-propagated species, viral diseases are a key problem regarding production and quality of the bulbs, causing gradual loss of yield and decrease in storage capacity. To improve the health quality of garlic seed, a virus-free stock of garlic cloves of the Amarante cultivar was obtained. The ability to distinguish garlic cultivars to detect varietal mixing after in vitro multiplication is extremely important, since correct identification is not possible until bulbs are produced. Random amplified polymorphic DNA markers were also used to differentiate cultivars while they are in vitro and not amenable to morphological discrimination. No difference was identified between the fingerprints of the virus-free or of the infected bulks of Amarante, showing that there was no clove mixing in the handling of material in the clonal multiplication phase.

Key words: Genetic divergence; Random amplified polymorphic DNA; Allium sativum

\section{INTRODUCTION}

In Brazil, garlic is one of the most important vegetable crops with regard to cultivated area $(17,640 \mathrm{ha})$. Garlic has a tremendous production volume, around 120,000 t yearly (FAO, 2003), which corresponds to approximately $1 \%$ of the world's total production of food crops. Although usually seed-sterile, garlic displays considerable variability, differing widely in morphological features. Different cultivars are adapted to a wide range of climatic regions, some being grown in the tropics, others being frost-hardy (Maab and Klaas, 1995). The different Brazilian garlic cultivars came mainly from somatic mutations and clonal selection of favorable characteristics by farmers (Sobrinho et al., 1999). While morphological differences between cultivars can be observed, only a few morphological traits are used for grouping garlic, and these can be affected by environmental conditions. Even with the introduction of new molecular marker systems during the last years, reports of these markers in garlic have been scarce (Lampasona et al., 2003). RAPD (random amplified polymorphic DNA) (Williams et al., 1990) has been successfully applied to the infraspecific classification of a number of crop species. In the genus Allium, close relations of $A$. cepa have been analyzed with RAPDs (Wilkie et al., 1993). Isozyme and RAPD have been used for assessing genetic relationships in garlic clones (Maab and Klaas, 1995), while Lampasona et al. (2003) and Ipek et al. (2003) successfully used AFLP (amplified fragment length polymorphism).

As garlic is vegetatively propagated, the health status of the crop is affected by both primary and secondary virus infections which accumulate in each crop cycle. Almost all garlic seed used in Brazil is contaminated with one or more pathogens, mainly viruses that play a main role in yield reduction and quality, also reducing the storage longevity of the harvested bulbs. With the aim to improve the health quality of garlic seeds, virus-free stocks of the garlic cultivar Amarante have been obtained by thermotherapy and shoot tip culture (Torres et al., 2000). The differentiation of garlic cultivars after in vitro multipli- 
cation is extremely important and the correct identification is not possible until the bulbs are produced. Markers obtained through RAPD may be used to differentiate the cultivars while they are not in a stage that allows morphological distinction (Welsh and McClelland, 1990). These markers are easy to obtain, have low costs compared to materials of other methods and may be an option for the quality control of the initial lots after thermotherapy and shoot tip culture.

The objective of this study was to characterize the genetic diversity of the 17 most planted Brazilian garlic cultivars and to analyze the quality control of garlic seed production of the cultivar Amarante after thermotherapy and shoot tip culture, through the use of RAPD markers.

\section{MATERIAL AND METHODS}

\section{Plant material and DNA extraction}

Young leaves were harvested from 17 clones of Allium sativum var. sativum (Mossoró, Quitéria, Chonan, Caçador, Amarante, Gigante de Lavínia, Hozan, Chinês São Joaquim, Jonas, Peruano, Centenário, Roxo Caxiense, Branco Mineiro, Gigante Roxo, Chinês Real, Chinezão, and Dourados) to be used in the genetic diversity study (Table 1). In addition, the leaves of five plants of each clone of the Mossoró, Quitéria, Chonan, Caçador, and Amarante cultivars, along with the leaves from 200 plants of virus-free Amarante obtained via thermotherapy and shoot tip culture (Torres et al., 2000) were also harvested. DNA was extracted by the CTAB-based method described by Doyle and Doyle (1987). DNA concentrations were quantified comparing the fluorescence intensities of the ethidium bromide-treated samples to those of a DNA standard dilution series on $1 \%$ agarose gel electrophoresis under UV light.

Table 1. Garlic accession number, names, bulb characteristics, secondary growth, and photoperiod requirement.

\begin{tabular}{|c|c|c|c|c|c|c|c|}
\hline $\begin{array}{l}\text { Accession } \\
\text { number }\end{array}$ & Name & $\begin{array}{l}\text { Identification } \\
\text { (CNPH number) }\end{array}$ & Bulb shape & Bulb color & Cloves per bulb & $\begin{array}{l}\text { Secondary } \\
\text { growth }\end{array}$ & $\begin{array}{l}\text { Photoperiod } \\
\text { requirement }\end{array}$ \\
\hline 1 & Gigante de Lavínia & 0041 & Oval & Purple & $8-12$ & Rare & Medium \\
\hline 2 & Hozan & 0051 & Oval & White & $10-15$ & Eventual & Medium \\
\hline 3 & Chinês São Joaquim & 0035 & Oval & Purple & $8-12$ & Rare & Medium \\
\hline 4 & Jonas & - & Round/flat & White & $7-10$ & Usual & High \\
\hline 5 & Peruano & 0077 & Round/flat & Purple & $6-12$ & Usual & Small \\
\hline 6 & Centenário & 0025 & Round/flat & White & $20-35$ & Usual & Small \\
\hline 7 & Roxo Caxiense & - & Round/flat & White & $7-10$ & Usual & High \\
\hline 8 & Branco Mineiro & 0012 & Round/flat & White & $20-25$ & Usual & Small \\
\hline 9 & Gigante Roxo & 0046 & Oval & Purple & $8-12$ & Rare & Medium \\
\hline 10 & Chinês Real & 0033 & Oval & Purple & $8-12$ & Rare & Medium \\
\hline 11 & Chinesão & - & Round/flat & White & $7-10$ & Usual & High \\
\hline 12 & Dourados & 0038 & Oval & Purple & $20-30$ & Usual & Medium \\
\hline 13 & Mossoró & 0072 & Round/flat & White & $20-25$ & Usual & Small \\
\hline 14 & Quitéria & - & Round/flat & White & $7-12$ & Usual & High \\
\hline 15 & Chonan & - & Round/flat & White & $7-9$ & Usual & High \\
\hline 16 & Caçador & - & Round/flat & White & $7-9$ & Usual & High \\
\hline 17 & Amarante & 0001 & Spherical & Purple & $8-12$ & Rare & Medium \\
\hline
\end{tabular}

Number of accessions corresponds to the Garlic Active Collection Number, held by the National Center of Vegetable Research (CNPH). 


\section{RAPD assays}

The amplification reaction conditions were as described in Ferreira and Grattapaglia (1998). Each $10 \mu \mathrm{L}$ of reaction mix contained: $10 \mathrm{mM}$ Tris- $\mathrm{HCl}, \mathrm{pH} 8.3,1.5 \mathrm{mM}$ $\mathrm{MgCl}_{2}, 1.0 \mu \mathrm{g} / \mu \mathrm{L}$ BSA, $0.2 \mathrm{mM}$ of each dNTP, $0.4 \mu \mathrm{M}$ primer, $7.5 \mathrm{ng}$ genomic DNA and 1 unit Taq polymerase, overlaid with $50 \mu \mathrm{L}$ mineral oil to prevent evaporation. RAPD reactions were performed in an MJ Research Thermal cycler programmed for 40 cycles of $1 \mathrm{~min}$ at $92^{\circ} \mathrm{C}, 1 \mathrm{~min}$ at $35^{\circ} \mathrm{C}$ and $2 \mathrm{~min}$ at $72^{\circ} \mathrm{C}$. Reaction products were separated by electrophoresis on $1.5 \%$ agarose gels, using Tris-borate-EDTA buffer system. Permanent records were obtained by photographing ethidium bromide-stained gels under UV light. Band sizes were determined by comparison with a 1-kb ladder in each gel.

The selection of bands for inclusion in the data set was based on band characteristics and reliability. The experiment was repeated with all primers to ensure the repeatability of the bands using the 17 accessions. The selection of bands for inclusion in the data set was then based on band reliability, clarity, signal strength, and resolution.

\section{RAPD data analysis}

All individuals were scored for the presence or absence of RAPD fragments, and the data were entered into a binary data matrix as discrete variables ( 1 for presence and 0 for absence). To generate similarity matrices, the data were subjected to the Jaccard algorithm. The resultant similarity matrices were utilized to group genotypes via the unweighted pair-group method of Sneath and Sokal (1973). Dendrograms were produced using the NTSYS-pc package for numerical taxonomy (Rohlf, 1992). Bootstrap analysis, with 1000 random samplings, was applied to estimate the reliability of the dendrogram branches using the BOOD version 3.0 program (Coelho, 2002).

Bootstrap analysis was also used to see if the number of polymorphic bands was high enough to provide accurate similarity estimates (Hallden et al., 1994; Garcia et al., 2004). To determine the coefficients of variance (CV) of genetic similarities, the bootstrap analysis was performed using an increasing number of bands, with 1000 random samplings, through the DBOOT version 1.1 program (Coelho, 2001).

\section{RESULTS AND DISCUSSION}

Five cultivars (Mossoró, Quitéria, Chonan, Caçador, and Amarante) were preliminarily tested with 568 RAPD primers to find polymorphic bands. From the 132 selected random primers, 75 were chosen based on the detected polymorphic bands and were used to analyze all 17 cultivars. These primers produced 206 unambiguous, readable and reproducible markers that were used to analyze the genetic diversity among the cultivars. The bootstrap sampling analysis revealed that the number of RAPD bands was suitable to estimate the coefficients of similarity (Figure 1). The use of maximum values of genetic distance CVs within each sample size was effective in determining the number of loci needed to obtain a maximum $\mathrm{CV}$ of $10 \%$, since this value is often cited as being necessary to obtain precise genetic distance estimates (Hallden et al., 1994; Thormann et al., 1994; Garcia et al., 2004). Thormann et al. (1994) reported that the number of bands required 


\section{Bootstrap analysis of RAPD markers}

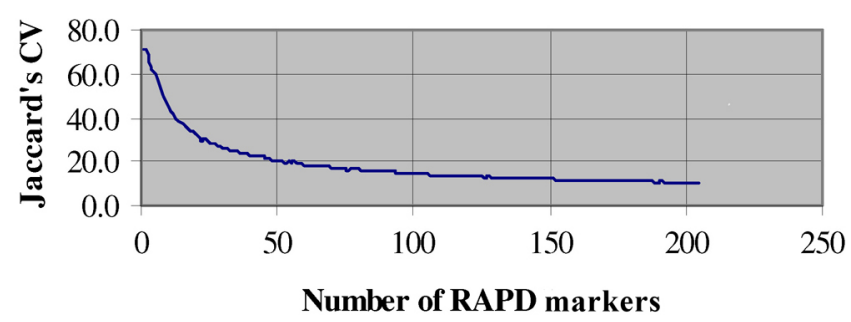

Figure 1. Evaluation of the coefficient of variation (CV) associated with Jaccard's similarity estimates through bootstrap analysis with variation in the number of RAPD markers.

for a mean $\mathrm{CV}$ of $10 \%$ was 327 for RAPD to estimate genetic relationships within and between cruciferous species.

The genetic similarities found with the Jaccard coefficient resulted in the dendrogram shown in Figure 2. High bootstrap values at most of the nodes supported the stability of the dendrogram. The grouping of most varieties agreed well with previous reports based on morphological characters, emphasizing the suitability of RAPD analysis for such studies. The Brazilian classification of garlic cultivars is based on morphological characters and on the production cycle (Sobrinho et al., 1999). In the current study, in general, the cultivars were clustered according to their growth cycle. The first group of the dendrogram includes the Amarante, Gigante de Lavínia, Gigante Roxo, Chinês Real, Chinês São Joaquim, and Dourado cultivars. These cultivars, from Mexican and Chinese origin, have a growth cycle of 140 to 170 days. They have little photoperiod requirement for bulb formation. The plants have an erect growth habit, the upper $1 / 3$ of the leaves develop horizontally and are larger than late-cycle cultivars. The clones in this group are, in general, secondary growth resistant, but very susceptible to foliar diseases such as Alternaria porri and Puccinia alii. The bulbs are more elongated than late-cycle bulb cultivars. The second cluster grouped the Hozan and Mossoró cultivars. These cultivars also have little photoperiod requirement to induce bulb development, but no other common morphological or agronomic characteristics. The third cluster grouped the cultivars Centenário, Chinesão, Branco Mineiro, Quitéria, Jonas, Caçador, Peruano, Roxo Caxiense, and Chonan. With the exception of the Peruano cultivar, all others are of Argentinean origin. They are late-cycle cultivars with a growth cycle longer than 180 days and a photoperiod requirement of a minimum of 13-h daylight. These cultivars are adapted to southern Brazil but may also be cultivated in the southeast, midwest and northeast of Brazil based on bulb vernalization to shorten the growth cycle and on the induction of bulb formation. The bulbs of these cultivars have a white color, round shape, and large cloves with purple skin in a small number (7 to 12 cloves per bulb). They also have longer shelf-life and higher market value than the other cultivar groups. In general, this study demonstrated that morphological and production cycle variation can be clearly related to the variation detected as RAPD polymorphism. Siqueira and Medina (1985) found that isozyme groups were also related 


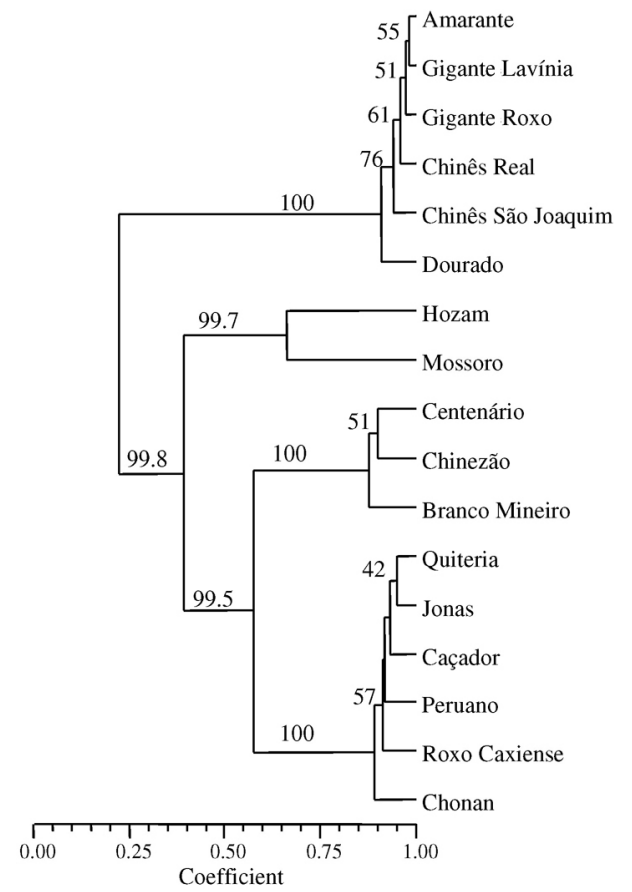

Figure 2. Dendrogram based on the unweighted pair-group method analysis of 17 garlic cultivars based on the genetic similarity computed by the analysis of 206 DNA fragments randomly amplified. The numerical values on branches are bootstrap values.

to the production cycle of garlic cultivars. One group contained the medium-maturity cultivars while the other contained late-maturity cultivars.

This study revealed that considerable genetic variation exists among the garlic cultivars tested, ranging between 16 and $98 \%$. The results obtained were in agreement with those reported by Lampasona et al. (2003) who found variation in Argentinean garlic clones of 24 to $97 \%$ using AFLP markers. Besides being an introduced crop in Brazil, large diversity has been introduced for a long time. The most unrelated variety from those studied was Mossoró, with an average similarity of $40 \%$ when compared to the other cultivars. By analyzing the relationship and variation among the cultivars of garlic mentioned, all of which are commercially available, this study now provides a cultivar and variety reference point for other researchers studying Brazilian garlic germplasm.

Two hundred plants of virus-free Amarante obtained by thermotherapy and shoot tip culture were submitted to RAPD markers to determine the quality control of multiplication. Clones of the Mossoró, Quitéria, Chonan, and Caçador cultivars propagated in vitro were used as the basis of comparison. As a result, sixteen markers were identified that only amplified in the Amarante cultivar (Figure 2). Recently, molecular markers have been utilized to test genetic fidelity during micropropagation due to the growing importance of this propagation form for some cultivated plants (Martín et al., 2002). This is the case with garlic which was submit- 
ted to thermotherapy and micropropagation to produce virus-free cloves. As many cultivars are handled at the same time, there is the risk of varietal mixture after the complete process. When tissue culture is employed, genetic variation in the propagated plants may appear which, when permanent, has been described as the production of somaclonal variants. This was not the main objective of this study, but if tissue culture is being employed for large clonal production, it is important to achieve a rapid and easy method to detect fingerprint differences. With the utilization of RAPD markers, no difference was detected among the fingerprints of virus-free or infected samples of the Amarante cultivar, nor were there similarities among this cultivar fingerprint and those of the other four that were propagated in vitro. Therefore, it was shown that there was neither varietal mixing nor any detectable variability as a result of the manipulation process of the analyzed material. In addition, no morphological characters were detected among the same samples during eight years of field test except for the expected gain in yield in the virus-free material (Melo Filho, 2003).

In conclusion, since high bootstrap values at most of the nodes supported the stability of the dendrogram produced and since the grouping of most varieties agreed well with previous reports based on morphological characters, the present study emphasizes the suitability of RAPD analysis for garlic diversity analysis, which revealed that considerable genetic variation exists among the garlic cultivars tested. Additionally, RAPD markers, in this study, seemed to be adequate for quality control after in vitro multiplication, showing that there was neither varietal mixing nor any detectable variability as a result of the manipulation process of the analyzed material.

\section{ACKNOWLEDGMENTS}

The authors are grateful to the $\mathrm{CAB}$ program for the financial support.

\section{REFERENCES}

Coelho ASG (2001). DBOOD version 1.1. Lab. Genet. Vegetal, DBG/ICB/UFG, www.ufg.br.

Coelho ASG (2002). BOOD version 3.0. Lab. Genet. Vegetal, DBG/ICB,UFG, www.ufg.br.

Doyle JJ and Doyle JL (1987). Isolation of plant DNA from fresh tissue. Focus 12: 13-15.

FAO (2003). FAOSTAT: Agricultural data. http://apps.fao.org/faostat/collections?version=ext\&hasbulk=0\&subset=agriculture.

Ferreira ME and Grattapaglia D (1998). Introdução ao uso de marcadores RAPD e RFLP em análise genética. EMBRAPA, Brasília.

Garcia AAF, Benchimol LL, Barbosa AMM, Geraldi IO, et al. (2004). Comparison of RAPD, RFLP, AFLP and SSR markers for diversity studies in tropical maize inbred lines. Genet. Mol. Biol. 27: 579-588.

Hallden C, Nilsson NO, Rading IM and Sall T (1994). Evaluation of RFLP and RAPD markers in a comparison of Brassica napus breeding lines. Theor. Appl. Genet. 88: 123-128.

Ipek M, Ipek A and Simon PW (2003). Comparison of AFLPs, RAPD markers, and isozymes for diversity assessment of garlic and detection of putative duplicates in germplasm collections. J. Am. Soc. Hort. Sci. 128: 246-252.

Lampasona SG, Martínez L and Burba JL (2003). Genetic diversity among selected Argentinean garlic clones (Allium sativum L.) using AFLP (amplified fragment length polymorphism). Euphytica 132: 115-119.

Maab HI and Klaas M (1995). Intraspecific differentiation of garlic (Allium sativum L.) by isozyme and RAPD markers. Theor. Appl. Genet. 9: 189-197.

Martín C, Uberhuaga E and Pérez C (2002). Application of RAPD markers in the characterisation of Chrysanthemum varieties and the assessment of somaclonal variation. Euphytica 127: 247-253.

Melo Filho PA (2003). Detecção e caracterização molecular de Allexivirus e estudo de degenerescência em plantas de alho (Allium sativum L.) provocada por vírus. Doctoral thesis, Universidade de Brasília (UNB), Brasília.

Rohlf FJ (1992). NTSYS-pc numerical taxonomy and multivariate analysis system. Version 1.8. Exeter Software, 
Setauket.

Siqueira WJ and Medina FHP (1985). Morphological and electrophoretic characterization of garlic clones (Allium sativum). Bragantia 44: 357-374.

Sneath PHA and Sokal RR (1973). Numerical taxonomy: the principles and practice of numerical classification. Freeman and Company, San Francisco.

Sobrinho JAM, Charchar JM and Aragão FAS (1999). Caracterização morfológica de germoplasma de alho por análises multivariadas, componentes principais e variáveis canônicas. Hort. Bras. 17: 96-101.

Thormann CE, Ferreira ME, Camargo LEA, Williams PH, et al. (1994). Comparison of genetic relationship estimates among cruciferous species based on RFLP and RAPD markers. Theor. Appl. Genet. 88: 973-980.

Torres AC, Fajardo TVM, Dusi AN, Resende R de O, et al. (2000). Shoottip culture and thermotherapy in recovering virus free plants of garlic. Hort. Bras. 3: 192-195.

Welsh J and McClelland M (1990). Fingerprinting genomes using PCR with arbitrary primers. Nucleic Acids Res. 18: 7213-7218.

Wilkie SE, Isaac PG and Slater RJ (1993). Random amplified polymorphic DNA (RAPD) markers for genetic analysis in Allium. Theor. Appl. Genet. 86: 497-504.

Williams JG, Kubelik AR, Livak KJ, Rafalski JA, et al. (1990). DNA polymorphisms amplified by arbitrary primers are useful as genetic markers. Nucleic Acids Res. 18: 6531-6535. 